Harkness Fellowships of the Commonwealth Fund

THE British Committee of Award of the Commonwealth Fund announces the following elections, among others, to Harkness fellowships for 1960, tenable for one or two years in the United States: G. S. G. Beveridge (Edinburgh to Minnesota), chemical engineering; R. Y. Calne (Royal Free Hospital to Harvard), surgery ; B. Coleby (Low Temperature Research Station, Cambridge to University of California), food research; B. J. Deverall (Imperial College of Science and Technology, London to Wisconsin), plant pathology; J. E. Dove (Atomic Energy Research Establishment, Harwell to Harvard), physical chemistry; R. Hall (Royal Victoria Infirmary, Newcastle upon Tyne, to Harvard), medicine; A. M. Howard (The Guardian to Columbia), journalism; M. Kogan (Ministry of Education to Harvard), teacher training ; D. LyndenBell (Cambridge to California Institute of Tech. nology), astronomy; D. H. Mellor (Cambridge to Minnesota), chemical engineering; K. J. Reid (Cambridge to University of California), chemical engineering; I. C. Roddie (Belfast to Seattle), physiology ; A. C. Rose-Innes (Admiralty to Rutgers), electronics ; J. R. Taylor (Cambridge to University of California), nuclear physics; C. T. C. Wall (Cambridge to Institute for Advanced Study, Princeton), mathematics.

\section{André Mayer Food and Agriculture Fellowships}

THE Food and Agriculture Organization of the United Nations has announced that it will offer 10 or 12 André Mayer fellowships during 1960. These awards, valued at 150-360 dollars a month depending on the country where they are used, will be made under the following two groups: research, for unusually promising persons with research experience behind them who would offer a guarantee for the carrying out of independent research work; research training, for younger and promising individuals who have demonstrated an inclination towards and an aptitude for research work. Due consideration will be given to geographical distribution, to ensure that a proportion of the awards is given to candidates from countries where research facilities are not highly developed and the need for trained research workers is great. The subjects presented must be in relation to the Organization's activities which comprise : land and water development, plant production and protection, animal production and health, rural institutions and services, fisheries, forestry and forest products, nutrition (non-medical), atomic energy in food and agriculture, agricultural economies (commodities, statistics, economic analysis). Further information can be obtained from the Secretariat of the Food and Agriculture Organization, National Committee for the United Kingdom, Ministry of Agriculture, Fisheriesand Food, Whitehall Place (East Block), London, S.W.1.

\section{The Canada Council}

The second annual report of the Canada Council, which covers the year ended March 31, 1959, again stresses both the Council's difficulty in selecting recipients of grants anci that a grant once made is not automatically renewable (pp. vi +112 . Ottawa: The Canada Council, 1959). The report includes list of scholarship awards made during the year and also special projects and grants-in-aid to individuals. During its two years the Council has made capital grants totalling $12,816,564$ dollars to 31 different. universities and colleges, including 1,632,600 dollars to the University of British Columbia, 1,377,141 dollars to Queen's University, Kingston, and 1,050,000 dollars to the University of Western Ontario. Under the Scholarship and Fellowship Scheme, 571 awards were made totalling, including travel grants, $1,215,000$ dollars, and of these, 111 were in the arts, 236 in the humanities and 224 in the social sciences; and of the 79 senior fellowships, 23 were renewals from the previous year. Grants to organizations totalled $1,148,379$ dollars in the arts, 120,772 dollars in the humanities and 167,440 dollars in the social sciences, and 75,000 dollars was earmarked to assist Canadian universities in bringing eminent scholars to Canada for short periods and for interchange of scholars between universities in Canada.

\section{The Industrial Training Council}

THE first report of the Industrial Training Council covers the period from July 1958 to December 1959 (pp. 32. London: Industrial Training Council, 1960. 18.). The Council's immediate task is to try to ensure that training arrangements in industry will be adequate to enable the best use to be made of the abilities of all the young people available for employment in industry during the next fow years. The proper training of its workpeople is the responsibility of each industry, and the Council sees its main function as the encouragement of the employers' organizations and the trade unions in co-operation to take the necessary action. The Council is convinced that great scope exists for introducing systematic training in a wide range of industries to supplement traditional apprenticeship training of craftsmen. The bulk of the report comprises a summary of the action taken by some sixty industries, which together employ nearly two-thirds of all workpeople, to deal with the 'bulge', and nineteen industries known to be still considering the Carr Report are listed. The Council has also asked all industries to make some quantitative assessment of their future training needs for all the young workpeople they expect to recruit, for whom a planned scheme of training is desirable; but although some industries have made such assessments, insufficient information is available to form any overall picture. The Council has accepted the Government's offer of a grant-in-aid to promote the expansion of training for young people in the circumstances ereated by the 'bulge' and particularly to assist the appointment of training development officers, and the Council has approved assistance under this arrangement to the Cotton Board and the Booksellers' Association and has agreed to a third grant to the Hotel and Catering Institute. The Council has also appointed its first two training advisers, and is now studying the information it has collected to decide what problems need more detailed consideration and what further information can usefully be distributed. Five working committees have been set up for this task.

\section{National Museum of Wales}

THE year 1958-59 at the National Museum of Wales marked the retirement of Dr. F. J. North from the post of keeper of geology after a total service of more than forty-five years. The annual report quite properly pays high tribute to his services to the many tasks he undertook and the honours he received. Dr. North accepted the invitation of the Council to act for a while as a part-time special adviser to the 